\title{
GENE EFFECTS AND HERITABILITY FOR YIELD TRAITS IN TOMATO (SOLANUM LYCOPERSICUM L.)
}

\author{
RAVINDRA KUMAR* and K SRIVASTaVa \\ Department of Genetics \& Plant Breeding, Institute of Agricultural Sciences, \\ Banaras Hindu University Varanasi-221005 India \\ Keywords: Cross combination, Epistasis, Gene effects, Interaction, Traits
}

\begin{abstract}
Generation mean analysis is a key determinant in designing the appropriate breeding approaches for implementing new desirable character/s in crop varieties and also in studying inheritance of quantitative traits. Parents, F1, F2 and backcrosses exhibited significant digenic interactions in the majority of cross combinations in tomato. Cross combinations and characters indicated the adequacy of simple additive dominance for 50\% flowering (CO3 x Floradade, Pant T3 x Azad T5), branches/plant and plant height (CO3 x Floradade, Pant T3 x Kashi Sharad), and fruit/cluster (CO3 x Floradade) indicating absence of non-allelic interactions. Duplicate type of epistasis occurred for 50\% flowering (CO3 x Floradade, Kashi Amrit x Kashi Sharad), branches/plant (CO3 x Floradade, Kashi Amrit x Kashi Sharad, Pant T3 x Kashi Sharad), plant height (CO3 x Floradade, Pant T3 x Kashi Sharad), fruit/plant (CO3 x Floradade, Pant T3 x Azad T5, Kashi Amrit x Kashi Sharad, Pant T3 x Kashi Sharad), fruit weight (CO3 x Floradade, Pant T3 x Azad T5), fruit/cluster (Kashi Amrit x Kashi Sharad, Pant T3 x Kashi Sharad), yield/plant (CO3 x Floradade, Punjab Upma x Azad T5, Pant T3 x Kashi Sharad) indicating selection strength should be lenient in the earlier and rapid in later generations because advancement should be through selection. Characters governed by additive components were predominant in fruit/plant and plant height, indicating direct selection for improvement of these traits.
\end{abstract}

\section{Introduction}

Yield and its components are the most important morphological traits for cultivar improvement in tomato (Solanum lycopersicum L.). However, yield is a complex trait, affected by genetic and environmental factors, in which various biotic (Scott and Jones 1990, Foolad and Lin 2001) and abiotic factors. The inherent yielding ability of a species is based on the effective selection process and other yield related characters may be utilized in breeding for higher yield. In the case of tomato, total fruit yield depends on branches, flowers, fruits number and fruit weight; however, they are controlled by various genetic and environmental factors (Singh et al. 1989; Zdravkovic et al. 1998). An understanding of the mode of inheritance of yield and its contributing traits is necessary for the appropriate choice of selection criteria for development of high-yielding hybrids and cultivars.

Genes for yield and its components can be assessed by generation mean analysis. Different models have been developed for analysis of generation means (Anderson and Kempthorne 1954, Hayman 1958, Gamble 1962). Procedures used to evaluate mean and variance of quantitative characters were proposed using generations: parents (P1 and P2), F1, F2 and backcrosses (BC1 and BC2). Additive (d) and dominance (h) are parameters of gene actions for additive dominance model (Mather and Jinks 1982). The goal of study to evaluate digenic non-allelic interactions controlling yield components and yield in F1 combinations and to determine the yield component that affects yield to a greater extent to define efficient selection for increasing yielding ability. Breeding for better genotypes necessitates a comprehensive understanding of the genetic mechanisms affect yield components because various important characters are influenced by fixed

*Author for correspondence: <godwalravindra@gmail.com>. 
and non fixed genes are demonstrated to contribute to the genetic mean of any plant population. For tomato development, additive variation should be helpful for successful selection of superior individuals in segregating populations, because selective gains will depend on gametic variation. The characters governed by additive components were predominant in fruit/plant, pericarp thickness and plant height, indicating direct selection for improvement of these traits.

\section{Materials and Methods}

The experiments were conducted at the Vegetable Research Farm, Banaras Hindu University, Varanasi, India located in the middle Gangetic plain (latitude: $25^{\circ} 19^{\prime} 59^{\prime \prime} \mathrm{N}$, longitude: $83^{\circ} 00^{\prime} 00^{\prime \prime} \mathrm{E}$ at $77 \mathrm{~m}$ above sea level). The climate is humid subtropical with large variations between summer and winter temperature. The soil was a with sandy loam soil having surface $\mathrm{pH} 8$. Varanasi falls in a semi-arid to sub humid climate with moisture deficit index between 20-40. The monsoon is in the latter half of June and lasts to the beginning October. Rain showers also occur during winter with average annual rainfall of approximately $1100 \mathrm{~mm}$. Day time temperature ranges from $9^{\circ}$ to $42^{\circ} \mathrm{C}$, with May and June being the hottest months a cold period between November and January. Mean relative humidity is approximately 65 to $70 \%$ rising to $80 \%$ during the rainy season and $30 \%$ during dry season.

The crosses CO3 x Floradade, Punjab Upma x Azad T5, Pant T3 x Azad T5, Kashi Amrit x Kashi Sharad and Pant T3 x Kashi Sharad were made by manual emasculation and hand pollination. The six generations viz parents, F1, F2 and back crosses for each population were established during winter seasons of 2010-2011, 2011-2012 and 2012-2013.

Generation mean analysis of populations and scaling tests (Mather 1949, Cavalli 1952) were carry out based on the assumption that populations of the plants have non-homogenous variances (Mather and Jinks 1971). Effect of genes (including no-allelic interactions) was measured with a 6 parameter model (Hayman 1958) and variance components (additive, dominance and environment) were estimated with a three Parameter model (Jinks and Jones 1958; Mather and Jinks 1971). Broad sense (bs) and narrow sense (bn) heritability was estimated with a degree of dominance ratio (Zdravkovic et al. 1998). Data were analyzed by Windostat Version 9.3 from Indostat Services, Hyderabad.

\section{Results and Discussion}

The results of the analysis of variance revealed significant variations between generations for all variables, demonstrating the presence of genetic variability and the possibility of fruit yield selection.

Gene action: The Mean comparison was done in six types of generations (Table 1), of which the crosses CO3 x Floradade, Punjab Upma x Azad T5, Pant T3 x Azad T5 and Kashi Amrit x Kashi Sharad reveals early flowering, while cross Pant T3 x Kashi Sharad exhibited late flowering. Present study based on six parameter model reveals that earliness is a desirable character in tomato, and favors of the market. The less days to flowering, is one of the peculiar indicator for earliness.

Further, the opposite signs of dominance (h) and dominance $x$ dominance (l) in $F_{1}$ crosses CO3 x Floradade and Kashi Amrit x Kashi Sharad, exhibit duplicate type of epistasis. The result reveals that selection intensity should be mild and intense for the earlier and later generations, respectively. Similarly, dominance $\mathrm{x}$ dominance gene effects were significant in positive direction for $50 \%$ flowering. 


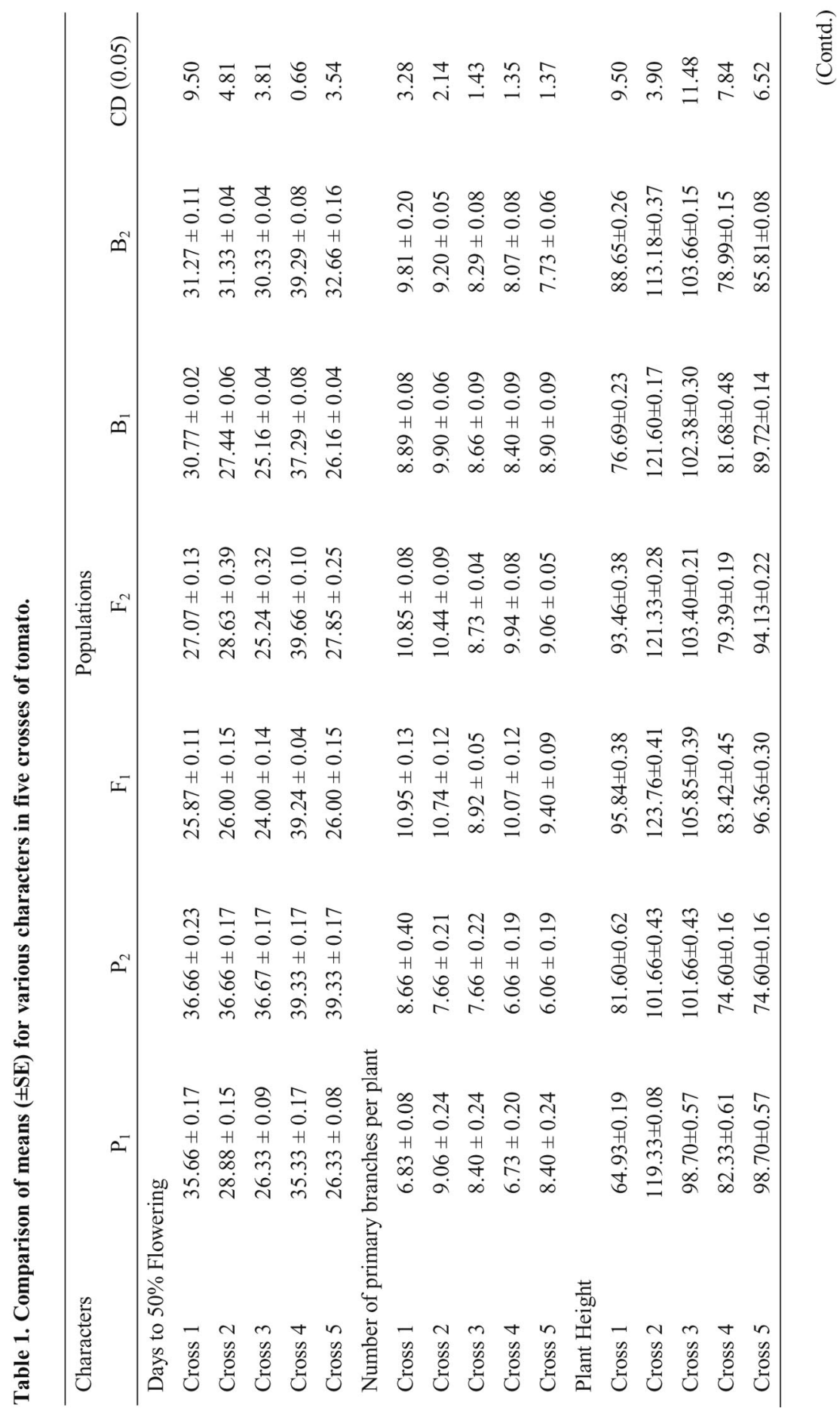


Mean comparison (Table 1) among the six generations of cross combinations $\mathrm{CO} 3 \mathrm{x}$ Floradade, Punjab Upma x Azad T5, Kashi Amrit x Kashi Sharad exhibited more primary branches than the cross Pant T3 x Azad T5 and Pant T3 x Kashi Sharad. The additive x additive (i) gene effect was found significant for primary branches under six parameter model. Therefore, this observation can be improved by simple selection method, whereas, the opposite signs of dominance (h) and dominance $\mathrm{x}$ dominance (1) for three crosses (CO3 x Floradade, Kashi Amrit x Kashi Sharad, Pant T3 x Kashi Sharad) suggest duplicate type of gene interaction.

Mean comparison (Table 1) among the six generations of cross Punjab Upma x Azad T5 showed high plant height than all the remaining crosses. Further, Three parameter model for plants reveal that all the five crosses except $\mathrm{CO} 3$ x Floradade and Pant T3 x Kashi Sharad indicate inadequacy. The application of six parameter model reveals positive and significant dominance gene effect in crosses Pant T3 x Azad T5 and Kashi Amrit x Kashi Sharad, Similarly.

Cross Kashi Amrit x Kashi Sharad find positively and significant additive $\mathrm{x}$ additive (i) gene effect. In addition to this, only crosses CO3 x Floradade and Pant T3 x Kashi Sharad manifested duplicate type of epistasis. An importance of both additive and non-additive gene effects was realized with preponderance of non-additive gene effects; therefore, population development approaches like recurrent selection and bi-parental mating would be more effective to accumulate desirable genes.

Mean comparison (Table 1) among the six generations of cross combinations Punjab Upma $x$ Azad T5, Pant T3 x Azad T5 and Pant T3 x Kashi Sharad exhibited higher fruits/plant than the cross $\mathrm{CO} 3$ x Floradade and Kashi Amrit x Kashi Sharad. The six-parameter model indicated the significance of additive gene effect (d) for fruit/plant in cross combinations $\mathrm{CO} 3 \times$ Floradade, Punjab Upma x Azad T5, Kashi Amrit x Kashi Sharad, that can be improved through simple selection procedure.

Dominance $\mathrm{x}$ dominance (1) gene effect was found significant in the all cross combinations. However, crosses CO3 x Floradade, Pant T3 x Azad T5, Kashi Amrit x Kashi Sharad, Pant T3 x Kashi Sharad depicted opposite signs of (h) and (l) type of gene effects indicating duplicate type of epistasis.

The $\mathrm{F}_{2}$ generations of three crosses CO3 x Floradade, Pant T3 x Azad T5, Pant T3 x Kashi Sharad showed highest magnitudes of fruit weight. In six-parameter model, fruit weight was governed by dominant gene effect in crosses $\mathrm{CO} 3$ x Floradade, Pant T3 x Azad T5 revealing the duplicate type of epistasis. The negative sign of dominance effect exhibits that alleles from males of cross Pant T3 x Kashi Sharad are recessive to alleles for fruit weight from females.

Mean comparison (Table 1) between the six generations of cross $\mathrm{CO} 3$ x Floradade showed higher fruit/cluster than the all remaining cross combinations. In the six parameter model, crosses CO3 x Floradade, Punjab Upma x Azad T5, Kashi Amrit x Kashi Sharad revealed additive (d) type of gene effects which means that this character can be improved through selection procedure. In addition to this, crosses Kashi Amrit x Kashi Sharad and Pant T3 x Kashi Sharad exhibited duplicate type of epistasis. All the three types of epistasis viz., (i) and (1) were found significant in cross Kashi Amrit x Kashi Sharad.

All five cross combinations having high mean value for fruit yield. Cross combinations $\mathrm{CO} 3 \mathrm{x}$ Floradade, Punjab Upma x Azad T5 and Pant T 3 x Kashi Sharad showed significantly negative dominance gene effect for fruit yield per plant. While, interactions of dominance $\mathrm{x}$ dominance (1) gene effects were exhibited positively significant in entire cross combination. According to above findings, fruit yield showed duplicate type of epistasis in most of the cross.

Devi et al. (2005) reported importance of additive gene effects for early flowering, whereas, only dominance (h) gene effect was found to be significant for crosses $\mathrm{CO} 3 \times$ Floradade. 
However, the opposite signs of dominance (h) and dominance x dominance (l) in crosses $\mathrm{CO} 3 \mathrm{x}$ Floradade and Kashi Amrit x Kashi Sharad exhibited duplicate type of epistasis, suggesting the selection intensity should be mild in the earlier and intense in the later generations because it marks the progress through selection. Similarly, dominance $\mathrm{x}$ dominance gene effects were significant in positive direction for 50\% flowering by Droka et al. (2013). Therefore, this trait can be improved through simple selection, whereas, the opposite signs of dominance (h) and dominance x dominance (1) for three crosses (CO3 x Floradade, Kashi Amrit x Kashi Sharad, Pant T3 $x$ Kashi Sharad) suggest duplicate type of gene interaction. Similar findings for branches were also reported by Droka et al. (2013); Shalaby (2013).

An importance of gene effects (both additive and non-additive) was realized with majority of non-additive gene effects; therefore, population improvement methods like bi-parental mating design and recurrent selection would be useful to accumulate desirable genes and to break undesirable linkages. The results of additive as well as dominance type of gene effects were in conformity with Shalaby (2013; Gongolee et al. (2015); Kanneh et al. (2016).

Dominance $\mathrm{x}$ dominance (l) gene effect was showed significant in the entire crosses. However, crosses CO3 x Floradade, Pant T3 x Azad T5, Kashi Amrit x Kashi Sharad and Pant T3 $\mathrm{x}$ Kashi Sharad depicted opposite signs of (h) and (l) type of gene effects indicating duplicate type of epistasis. The additive gene effects were also reported by Sharma (2004); Aswani and Khandelwal (2005) for number of fruits.

Fruit yield showed duplicate type of epistasis in the entire cross combinations except in crosses CO3 x Floradade, Punjab Upma x Azad T5 and Pant T3 x Kashi Sharad. This kind of epistasis normally hinders the improvement through selection as the appearance of duplicate epistasis decreases the variations in $F_{2}$ and later generations. As a result, selection should be postponed until there is a significant level of gene fixation. However, in the majority of cases, the predominant contribution of non-additive gene effects was assessed. Whereas, among the yield related traits was controlled by both additive and non-additive gene effects. Therefore, it would be difficult to improve these attributes through direct selection and it should be delayed up to reduction of dominance in later segregating generations and followed by improvement in early segregating generations. Both additive and dominance gene effects on yield have been confirmed in this study, with prevalence of dominance gene action, which is in accordance to the results reported by Chandrasekhar and Rao (1989). These findings were in agreement with Zdravkovic et al. (2011) for fruit yield/plant.

Duplicate epistasis: The signs of dominance (h) and dominance $\mathrm{x}$ dominance (l) gene effects were opposite in the case of plant height, 50\% flowering, branches/plant, fruits/plant, fruit weight, yield/plant (CO3 x Floradade); yield/plant (Punjab Upma x Azad T5); fruits/ plant, fruit weight (Pant T3 x Azad T5); 50\% flowering, branches/plant, fruits/plant, fruits/cluster (Kashi Amrit x Kashi Sharad); plant height, branches/ plant, fruit/plants, fruits/cluster and yield/plant (Kashi Amrit $\mathrm{x}$ Kashi Sharad) suggesting duplicate type of interaction in these traits. This types of epistasis frequently prevents improvement through selection, therefore a high magnitude of dominance and (l) type of interaction effects are unexpected. No complimentary interaction was exhibited in the genetic regulation of the examined variable since Since none of signs of (h) were similar to the (1) type of epistasis (Table 2).

Positive or negative sign of additive $\mathrm{x}$ additive (i) interaction shows association and dispersion of alleles in parents, respectively. Therefore, negatively significant diversity in the study exhibited alleles dispersion in parents for plant height (CO3 x Floradade, Punjab Upma $\mathrm{x}$ Azad T5, Pant T3 x Azad T5), 50\% flowering (Kashi Amrit x Kashi Sharad), all five crosses of primary branches/plant, fruits/plant, fruit weight, fruits/cluster (CO3 x Floradade, Pant T3 x Azad 


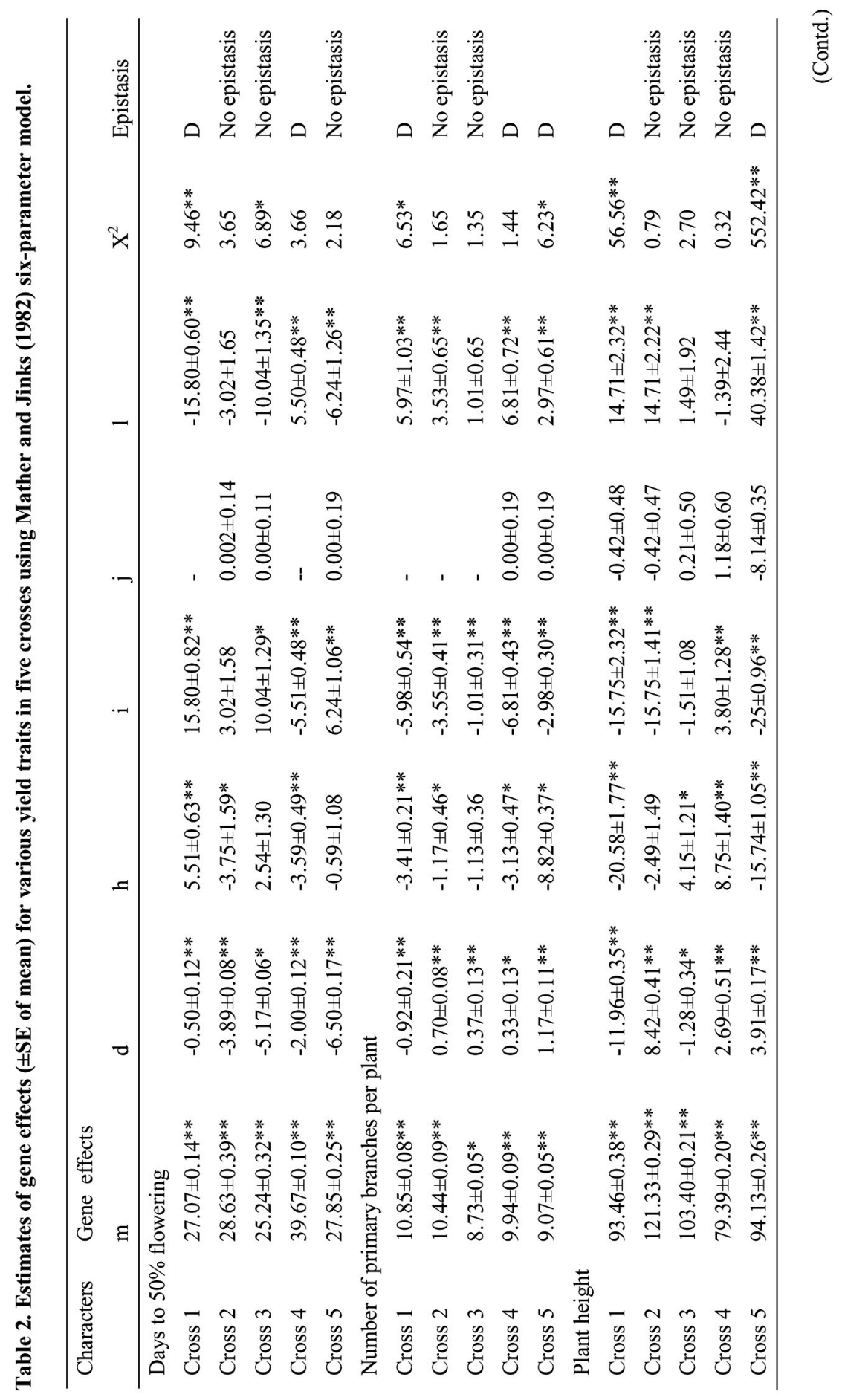




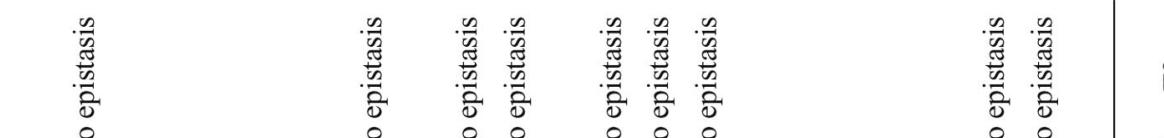

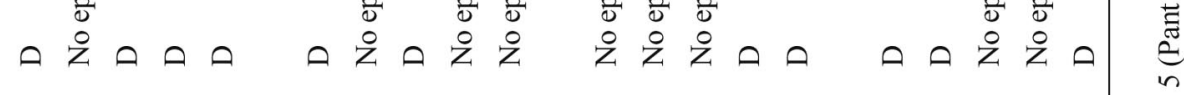

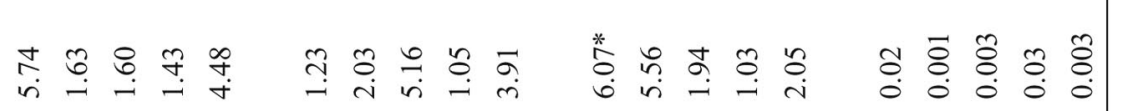

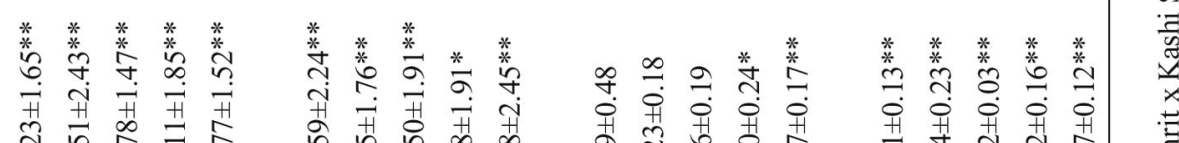

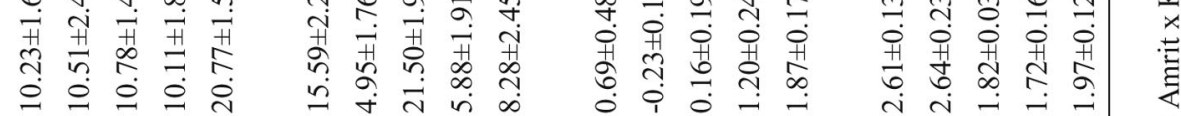

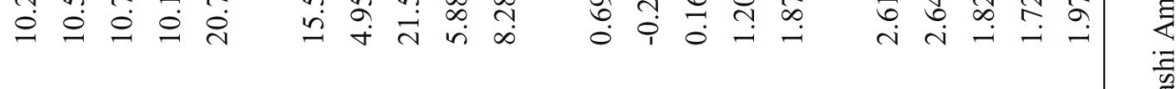

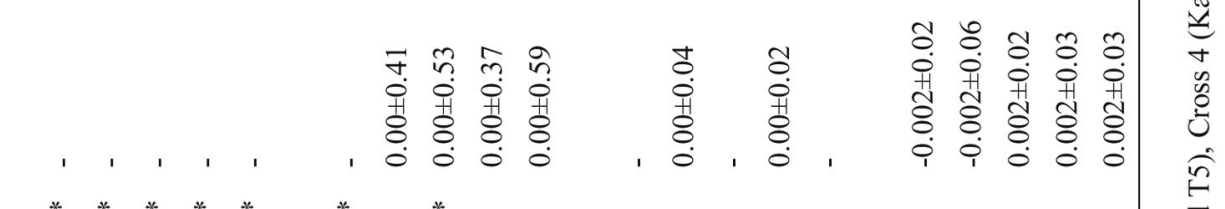

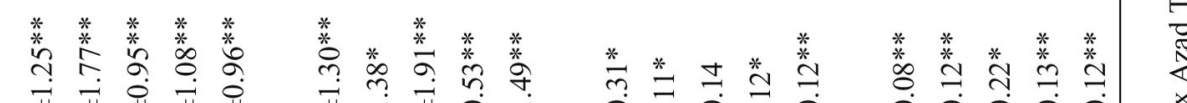

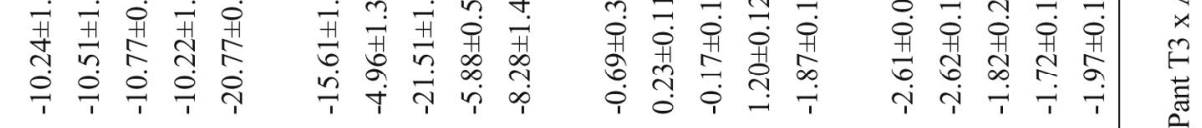

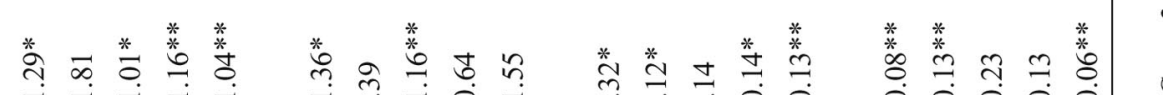

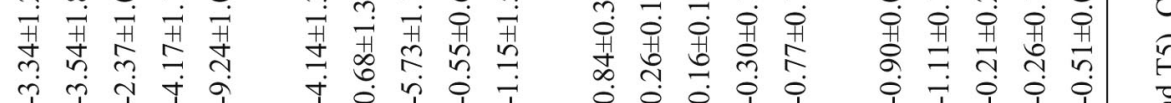
गे

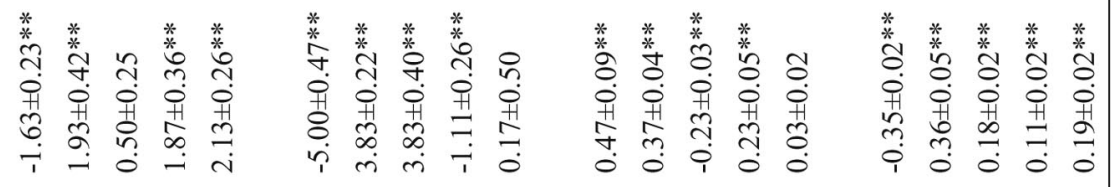

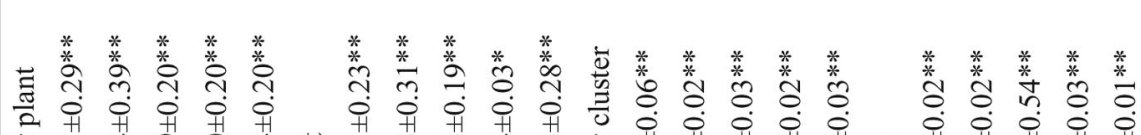

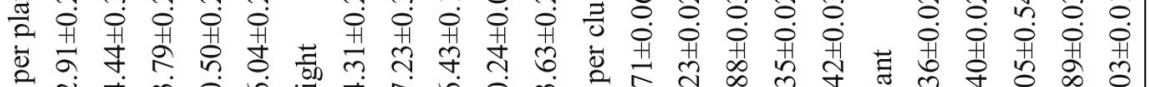

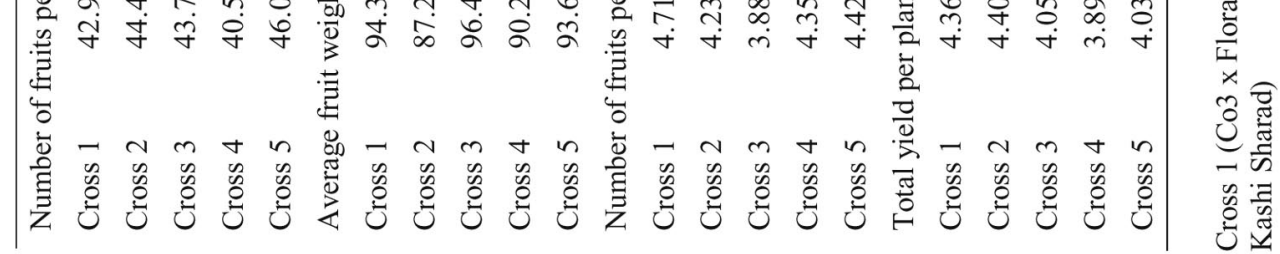


T5, Pant T3 x Kashi Sharad) and yield/plant (Pant T3 x Azad T5, Kashi Amrit x Kashi Sharad, Pant T3 x Kashi Sharad).

Variance components and heritability estimates: Large variations were observed for both components with $\sigma 2 \mathrm{~A}$ ranging from -10.011 to 8.174 and $\sigma^{2} \mathrm{D}$ from -10.021 to 20.544 . The additive and dominance variance differed greatly from cross to cross. Backcross method/SSD method/pedigree selection can be use for the listed traits the magnitude of dominant variance is less than the additive variance for all variable. Table 3 shows the estimates of the variance model, broad and narrow sense heritability values, and the ratio of degree of dominance.

The average dominance ratio was more than unity for plant height (Punjab Upma x Azad T5, Kashi Amrit x Kashi Sharad, Pant T3 x Kashi Sharad), for 50\% flowering and fruit weight (Punjab Upma x Azad T5, Pant T3 x Azad T5, Kashi Amrit x Kashi Sharad), for branches, fruits and total yield (Punjab Upma x Azad T5, Pant T3 x Azad T5, Kashi Amrit x Kashi Sharad, Pant T3 x Kashi Sharad), for fruits/cluster (CO3 x Floradade, Punjab Upma x Azad T5, Kashi Amrit x Kashi Sharad, Pant T3 x Kashi Sharad) which showed the importance of the dominance gene effects that is in agreement with high heritability (narrow sense) for these traits.

Broad-sense heritability were relatively high for all traits and ranged from 0.70 to 7992.76 depending on the trait and cross combination. The additive component was responsible for a significant proportion of the variation in fruit yield and weight. Moderate heritability was observed for fruit weight and total yield/plant in cross Pant T3 x Azad T5. All traits had moderate to low heritability estimates. The estimates of heritability (broad-sense) were high for early maturity, total yield and fruit weight as well as heritability estimates in narrow sense were high for early yield and fruit weight.

Heritability is an expression of the extent to which the genetic constitutions of an individual control its phenotype. Broad-sense heritability reflects all possible genetic contributions to a population's phenotypic variance (Rao et al. 2008; Dhaliwal and Chahal 2005) and it includes effects of gene due to additive variance, dominance variation or which act epistatically. Narrowsense heritability estimates are based on additive genetic variance (fixable component) and are stronger indicators of selection effectiveness in genetically heterogeneous populations than broadsense heritability (Robinson et al. 1949). In this study, the majority of cross combinations for total yield traits like fruits number and fruit weight had low magnitudes of dominance and greater estimations of heredity due to environmental variations (broad and narrow-sense).

Considerable difference was observed in both the type heritabilities in all cross combinations. All traits had relatively high broad-sense heritability, which ranged from 0.70 to 7992.76 depending on the characters and hybrid combinations. A considerable amount of the variation in weight and fruit yield was due to the additive component. Fruit weight and yield were significantly affected by the additive component. Moderate heritability was observed for fruit weight and yield in cross Pant T3 x Azad T5. All traits had moderate to low heritability estimates. The estimation of heritability in broad-sense were high for early maturity, yield and fruit weight as well as estimation heritability (narrow sense) were high for early maturity and fruit weight by Shalaby (2013). The narrow sense heritability almost high then broad sense heritability because characters controlled by additive genes and the selection for improvement of such character would be rewarding.

The genetic variation in these hybrids was predominantly caused by additive effects, according to estimates of narrow sense heritability. In the improvement of autogamous plants such as tomato, the selected gains will be based only on gametic variation, additive (fixable) variance is extremely important and allows for successful selection of superior individuals in F2 and later 


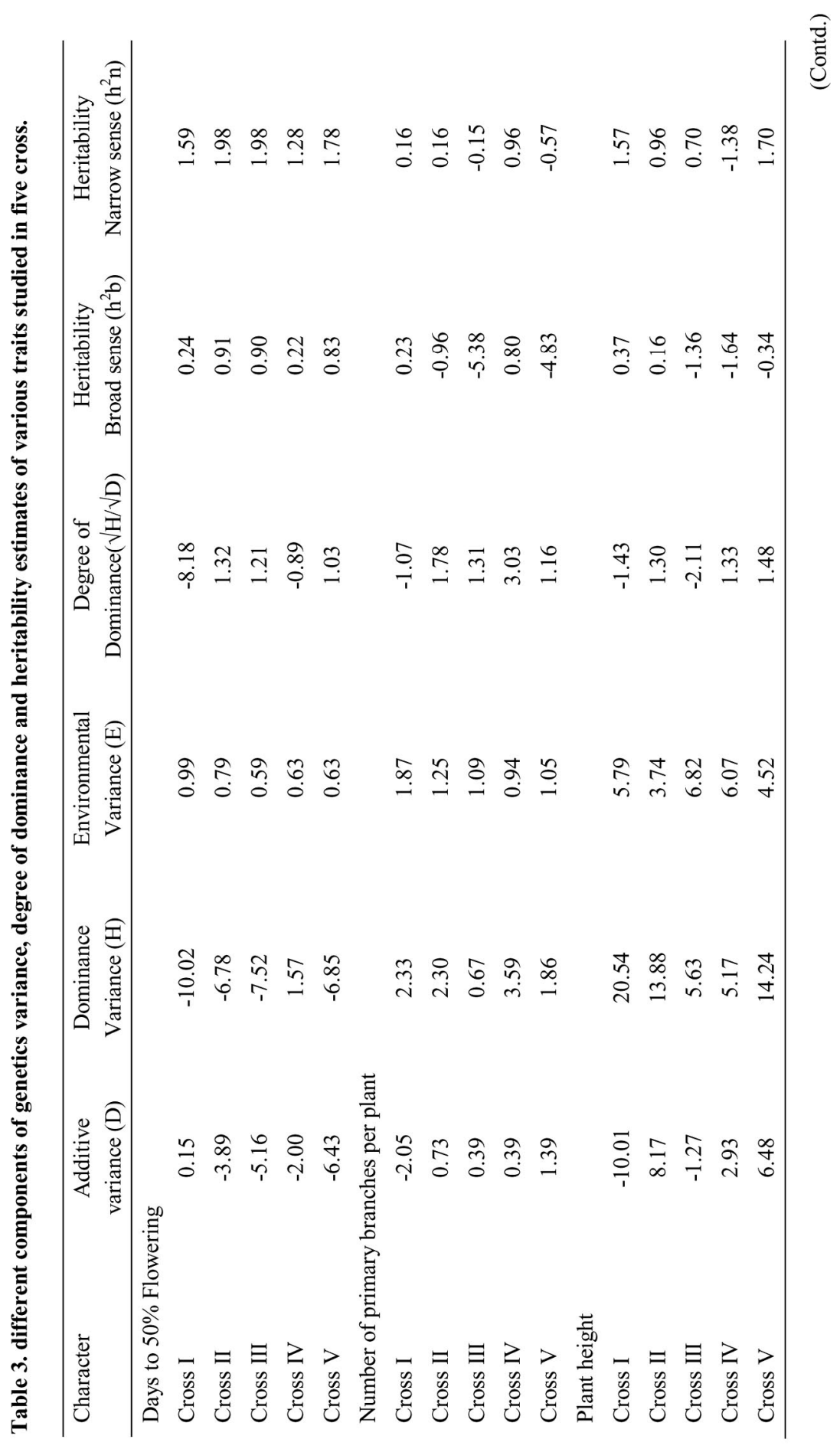




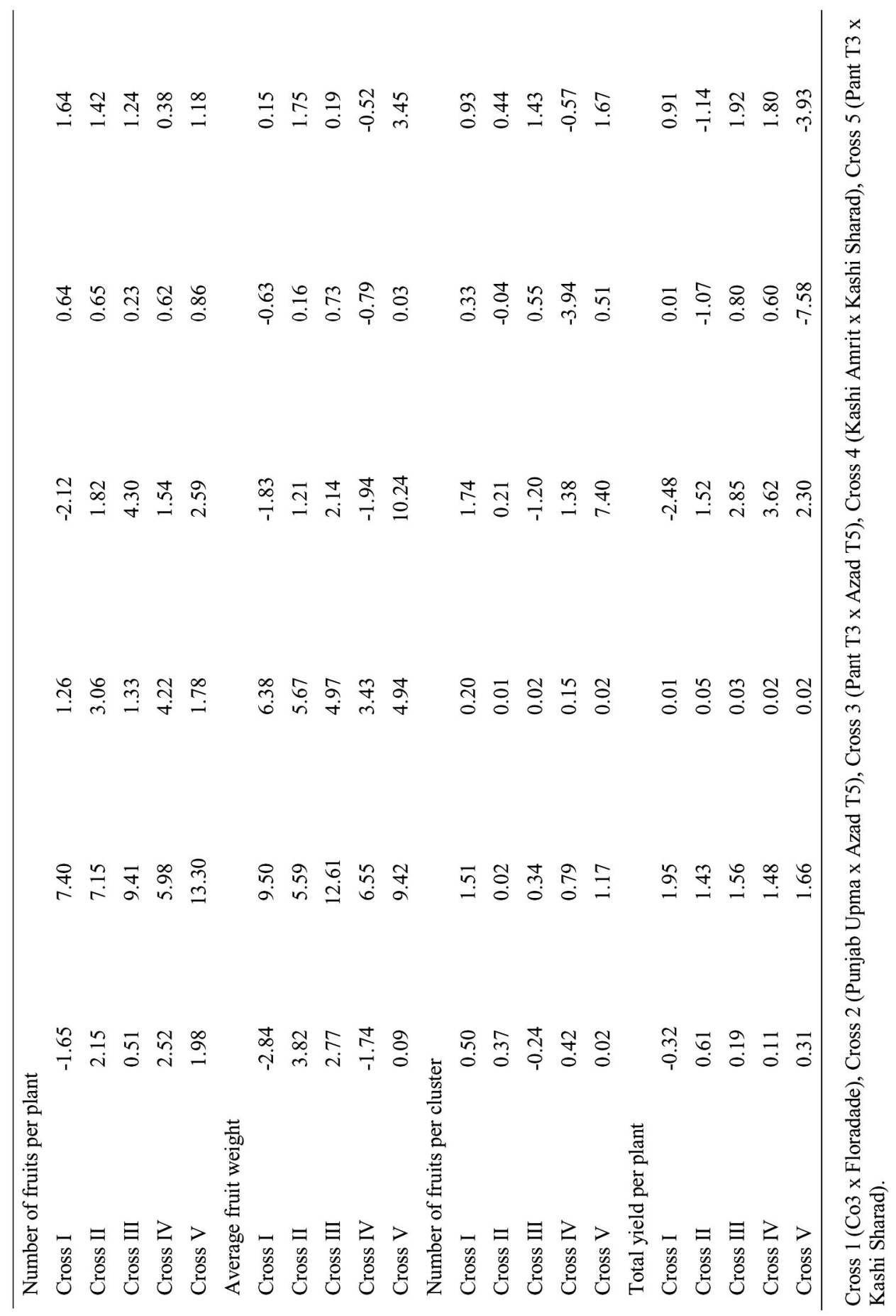


populations (Warner 1952). Therefore, backcross method, pedigree method, SSD methods are suggested for advancing the segregating plant populations (Bernado 2003).

This study suggests that selection strength should be modest in the earlier and acute in the subsequent generations because it marks the improvement through selection. These finding exhibited that for development of tomato, additive variation is of high significance and makes more useful to successfully selection of superior plant in segregating plant population, because the selective diversity will depend on gametic variation.

\section{References}

Anderson V L and Kempthorne O 1954. A model for the study of quantitative inheritance. Genetics 39: 883-898.

Aswani RC and Khandelwal RC 2005. Combining ability studies in brinjal. Indian J. Hort. 62: 37-40.

Bernado R 2003. On the effectiveness of early selection in self pollinated crops. Crop Sci. 43: 1558-1560.

Cavalli L 1952. An analysis of linkage in quantitative inheritance. In: Reeve, E.C.R., Waddington, C.H. (Eds.), Quantitative Inheritance. MNSO, London, pp. 135-144.

Chandrasekhar P and Rao MP 1989. Studies on combining ability of certain characters in tomato. South India Hortic. 37: 10-12.

Devi E S, Singh N B, Devi A B, Singh N G and Laishram J M 2005. Gene action for fruit yield and its components in tomato (Lycopersicon esculentum Mill.). Indian J. Genetics and Plant Breeding 65(3): 221-222.

Dhaliwal M S and Chahal D S 2005. Inheritance of important quality attributes of tomato under lowtemperature field conditions. Adv. Hort. Sci. 19(3): 158-162.

Droka D, Kumar R, Joshi S and Yadav RK 2013. Genetics of yield and yield contributing traits in tomato under low temperature grown climatic regime, Indian J. Hort. 70(2): 243-247.

Foolad MR, Lin GY (2001) Genetic analysis of cold tolerance during vegetative growth in tomato, Lycopersicon esculentum Mill. Euphytica 122: 105-111.

Gamble E E 1962. Gene effects in corn (Zea mays L.). I. Separation and relative importance of gene effects for yield. Can. J. Plant Sci. 42: 339-348.

Gongolee GAK, Osei MK, Akromah R, Nyadanu D and Aboagye LM 2015. Evaluation of some introduced tomato Cultivars. Horizon J Agri Food Sci 1: 001-006.

Hayman B I 1958. The separation of epistatic effects from additive and dominance variance in generation means. J. Heredity 12: 371-90.

Jinks J L and Jones RM 1958. Estimation of the components of heterosis. Genetics 43: 223-234.

Kanneh SM, Osei MK, Akromah R, Gyau J 2016. Generation mean analysis of yield and yield components of earl generations of interspecific crosses of tomato (Solanum lycopersicum L.). Int J Pl Breed Gen 10:98-103.

Mather K 1949. Biometrical Genetics. Dover Publication, Inc., New York.

Mather K and Jinks J L 1971. Introduction to Biometrical Genetics. Chapman and Hall Limited, London, pp. 249-252.

Mather K, Jinks JL 1982. Biometrical Genetics. 3rd eds. Chapman and Hall, London.

Rao E S, Munshi A D, Singh B and Kumar R 2008. Genetic analysis of yield and its components in tomato. Indian J. Hort. 65(2): 152-157.

Robinson H F, Comstock R E and Harvey PH 1949. Estimates of heritability and the degree of dominance in corn. Agron. J. 41: 353-359.

Scott SJ, Jones RA 1990. Generation means analysis of right-censored response time traits: low temperature seed germination in tomato. Euphytica 48:239-244.

Shalaby T A 2013. Mode of gene action, heterosis and inbreeding depression for yield and its components in tomato (Solanum lycopersicum L.), Scientia Horticulturae 164: 540-543. 
Sharma KC (2004) Inheritance of important characters in bacterial wilt resistant $\mathrm{x}$ susceptible tomato (Lycopersicon esculentum Mill.) crosses. Ann. Agric. Sci. 25: 403-405.

Singh UP, Tanki I and Singh RK 1989. Studies on order effect and epistatic components for yield in doublecross hybrids of tomato. Haryana J. Hort. Sci. 18:265-271.

Warner JN 1952. A method for estimating heritability. Agron. J. 44: 427-430.

Zdravkovic J, Pavlovic N, Girek Z, Brdar-Jokanovic M, Savic D, Zdravkovic M and Cvikic D 2011. Generation mean analysis of yield components and yield in tomato (Lycopersicon esculentum Mill.). Pak. J. Bot. 43(3): 1575-15.

Zdravkovic J, Markovic Z, Kraljevic-Balalic M, Zdravkovic M and Sretenovic-Rajicic T 1998. Gene effects on number of fruits per flower branch in tomato. Acta Hort 487: 361-366.

(Manuscript received on 25 October, 2018; revised on 18 February, 2019) 